\title{
Bioarchitecture - a new vision of energy sustainable cities
}

\author{
Alicja Krzemińska ${ }^{1, *}$, Anna Zaręba ${ }^{1}$, and Anna Dzikowska $^{2}$ \\ ${ }^{1}$ University of Wrocław, Faculty of Earth Sciences and Environmental Development, \\ pl. Uniwersytecki 1, 50-137 Wrocław, Poland \\ ${ }^{2}$ The International University of Logistics and Transport in Wrocław, ul. Sołtysowicka 19B, \\ 51-168 Wrocław, Poland
}

\begin{abstract}
Transformation of the natural environment will press the humanity to search for the new look at the problems of architecture and urban design. Nowadays passive houses construction is a standard and green roofs are incorporated in the design of contemporary cities. That's why city cluster will be successively transformed into sustainable bionic systems, which allows to protect the nature and stop further degradation and exploitation of public green space. The good examples of contemporary trend of designing in harmony with nature are energy sustainable underground buildings of Malcolm Wells, who in 60s designed his first energy sufficient construction. The underground cities and rock houses were built from the early beginning of architecture, with significant examples of cities: Sanmenxia in China in Henan Province, Matmata (Tunisia), Cappadocia (Turkey), Uplisciche (Georgia) or Brlhovce (Slovakia) etc. The underground buildings and cities, blending in with the background of topography, have a positive influence on the landscape and are energy sustainable. Climate responsive design materials create effective insulation, which allows to maintain the stable temperature inside the buildings. Bioarchitecture improves the microclimate in the neighborhood through increasing oxygen concentration in atmosphere and limiting of $\mathrm{CO}_{2}$ emission. Bioarchitecture represents new direction in changing the design priorities towards being closer with nature and it's needs.
\end{abstract}

\section{Introduction}

People have for centuries adapted their habitat to environmental conditions, guided mainly by the instinct of survival. To build the first primitive homes they used natural materials that they found or hunted. Homes were concentrated in settlements that provided people with a sense of security. They were built both on the ground and underground, for example, in the rocks. Underground housing structures can be found both in hot areas as well as where temperatures are low. The earth is a good thermal insulator, so that the temperatures in the underground homes provided them with adequate thermal comfort.

Contemporary environmental problems, including climate changes, environmental pollution, habitat changes and progressive destruction of the landscape, will certainly contribute to a new look at the issues of house construction as well as urban design, in a different way than before. Conventional perception and design of urban structure in the next decades will get changed, and ecological values and landscape values will be one of the top priorities for new trends in design [1]. First and foremost, the paradigm of development

* Corresponding author: alicja.krzeminska@uwr.edu.pl 
and space aesthetics will change, where the bionic system will be a determinant of its quality. However, the mentality of people must change, and the permission to build zero energy bionic houses, including houses built entirely or partly underground, that so far has often been in the zone of taboos, has to change as well.

\section{Historical conditioning. Earth sheltered buildings}

Recovering the harmony between nature and the world, in which man performs constant transformation is difficult. The cities, in which we live most often do not resemble green enclaves, and buildings - often in spite of their beauty, do not create unity with the natural environment. Negative changes in the surrounding environment force us to change our thinking and to enter another dimension of home and human settlements design (in both cities and villages). Current design trends are changing, as our ecological consciousness becomes a new paradigm of design, and design patterns take into account the coexistence of nature in the city and the creation of bionic construction systems - and therefore there are more and more buildings with green roofs and vertical gardens, which play important ecological functions in the city cluster. The modern and visionary projects inspired by nature were famous for Zaha Hadid, whose vision of futuristic buildings fits in perfectly with the new design challenges. Nowadays, more and more boldly is being talked about houses that are located underground or in hollow rocks. Breaking the taboos and the negative attitude of people to live underground, the natural environment might, in the future, recover the lost areas that have been changed or devastated as a result of human activities. In fact, it is a return to the original solutions, where protection against the changing weather conditions, but also the maintenance of a specific balance between human activity and nature, is an important element.

The idea of constructing underground houses is not new. All around the world a lot of that type of buildings can be found, including settlements and small towns. Examples of this may be houses in China, especially in the Provinces: Hunnan, Henan, Shanxi and Gansu [2]. Nearly 10 million people live there. An example of such a city is Sanmenxia in Henan Province, which, in 2005, was put on the National List of Monuments by Chinese authorities, assessing its cultural and historical value very high $[2,3]$. The first settlements in this area were established in the Bronze Age (around 2000-1500 BC), but in fact the city flourished during the reign of the Ming dynasty in the 14th century. The first inhabitants built the settlement almost entirely underground to survive under difficult climatic conditions. As a result, the town of around 10,000 houses was carved into a loess layer. The average house is situated about 6-7 meters under the ground surface, and its length is about 10-12 meters. The house geography is almost identical in all cases - a kitchen room, a bathroom, several bedrooms and chambers, dedicated to domestic animals, i.e. pigs and/or poultry. The whole was designed in the form of a cube, where its center - a kind of yard being a representative part of the house, did not have a roof. Besides, there was also a well in every house, which during the heavy rains also served as a receiver of excess water. The roof of the house was actually an area that could be used in a variety of ways - for example, an additional usable area for the householders, or it was partly used for farming purposes. These houses are very strong and energy efficient - they have quite a constant temperature inside, which gives a great comfort of use, and they are sound proof and earthquake resistant. There was, however, no direct connection between the houses, so than no additional connecting structures, such as tunnels. To get to another home, one had to go to the surface and then go down there, using the stairs. Similar idea of building is represented by sandstone houses in Matmat, located in central Tunisia, on the edge of the Sahara desert in the landscape of the Jabal Matmata Mountains. The hight of the house is approximately 8-10 metres, while the chambers are about 3 metres high [3-5]. The difference in conceptual design of the building 
is mainly the shape of the courtyard - unlike in Sanmenxia, in Matmata the courtyard is usually round. Also the height of the building and the rooms are different with different parameters - the buildings in Mamat are larger in size. Equally interesting is the village of Kandovan, situated in East Atrpatakan Province, Sahad Mountain, about $50 \mathrm{~km}$ from Tabriz in Iran, where the houses were carved into volcanic rocks, and the oldest of them could have been built up to 700 years ago. They have an exceptional structure and shape, which resemble a little the termite nests. Some of them are two- three storey constructions, while the rooms are about two metres high. Due to its unique architecture and its landscape, this place was listed on the National Hertiage Society, Iran $[3,6]$.

In Lijiashan, near the town of Qikou in Shanxi Province (China), there are examples of well-preserved cave houses that have been hollowed out on the slopes of Jiashan Moutain. These are the houses, where the decorative front wall with windows and large entrance doors is built of bricks, while the rest of the building is hollowed in the rock space [3]. The layout of chambers, however, is different from the one in Sanmenxia - they were arranged in a straight line rather than on the perimeter of the square. Moreover, the courtyards are open to the view of scenic landscape. As individual homes are located on terraces - the whole structure resembles in a sense multi-storey houses. This results in a unique combination of the house and the surrounding space - the usable space of the home becomes optically enlarged, and its direct opening to the landscape suggests that it belongs to the very place. It also gives an impression of the greater sense of security of the people living in these settlements, than in previously discussed cases.

Also very interesting constructions of rock houses made in volcanic tuff can be found in Slovakia, in Brhlovce. The very first information on the community dates back to 1245 [7]. The houses are made, excavated in rock as a whole and have usually one or two small windows and an entrance door. In Georgia, in Uplistsikhe, situated in the neighbourhood of the city of Gori in the region of Kartvelian, on the rocky banks or the river Mtkwari (Kura), there is a unique ancient rock city, whose construction is dated for about the $5^{\text {th }}$ century B.C. The homes have surprisingly large rooms, which are very often located on several levels of interconnected, excavated, corridors and stairs. The Uplisciche complex has very good infrastructure - including narrow roads and stairs leading to other homes [8]. The treasure of Turkey, Cappadocia, is also unique. Its underground, excavated in sediment rocks (tuff), houses, cloisters, churches, granaries, are self-sufficient underground cities, with very welldesigned, internal infrastructure, that allow residents to survive with adequate food supplies and to contact each other without going out to the surface. These homes are characterized by excellent thermography [3,9].

The largest and most interesting cities of Cappadocia, Kaymakli and Derinkuyu, are the towns of monks, connected by a 9 kilometre tunnel. Interestingly, these cities had a more than ten levels of communication with each other. Not only people, but also livestock could stay in specially designated rooms. The city needed to have a proper ventilation system, enabling people to live underground.

The above mentioned examples are characterised by the diversity (structure, division of space, or location, etc.), which, in majority of cases, results from their location and the climatic, physiographic, cultural and political conditions of a given space.

\section{Modern realizations of the concept of underground houses}

In today's world, there are many examples of buildings, that have been built underground and play either residential or service-utilitarian role - for example offices and shops are located underground. Subway stations, that are located under many cities, are also part of the subterranean model, in the same way like bunkers, that were built mostly in Europe as well as in the United States or China during the Cold War. Nevertheless, it is difficult to talk about 
their ecological function, as they were created mainly for military purposes, while shelters were built for the civilian population. At present, with the design paradigm shifting to conscious protection of natural environment and landscape values, many designers adapt their projects to new challenges, which gains recognition among ecologists and supporters of sustainable architecture.

Malcolm Wells was a great proponent of the construction of underground houses. He was an architect, who, in the 1960s, as an answer to a construction of a highway in the neighbourhood of his office, designed his office underground, and later designed many similar houses [10]. Wells had many followers, who used the concept of sustainable design in harmony with nature. Among them we can list William Morgan, who built a house on a dune, or who, properly speaking, built this house into a dune, in order to achieve greater stabilization of the building, or Peter Vetsch - the author of a futuristic mini housing estate, in northern Switzerland, in the town of Dietikon, where he designed and built nine houses, sharing a courtyard with a pond, that perfectly fits into the surrounding landscape at the same time increases its attractiveness [11]. A residence, built on the Greek island of Kea near Athens, designed by Marina Stassinopoulos and Konstantios Daskalakis is an interesting investment [12]. The project assumed complete adaptation to the specific environmental and geomorphological conditions of the island and special attention to the landscape. The building, in spite of geometric shapes, harmonises with the landscape due to its minimalist design. Nowadays, not only single underground homes are built, but also underground towns, such as Coober Pedy in Australia, about $680 \mathrm{~km}$ south of Alice Springs. Coober Pedy is a mining village that was established after the First World War with the arrival of opals miners to the area [13]. The houses were completely excavated in the rock and connected to a network of corridors resembling narrow roads. Today the city has about 3,500 inhabitants. There are houses, cafes and a theatre. The town functions in a perfect way and at the same time it has become a tourist attraction.

A new trend in ecological construction is, among others, construction of so-called Eartships, whose technology was developed and applied in practice by a famous US architect Michael Reynolds. The construction of these homes was based on recycled materials available to every human being, including mostly used car tires, cans, plastic and glass bottles, sand and earth [14]. At present there are about 3,000 of these types of buildings all over the world, mainly in the United States (most of them in New Mexico) as well as in Canada, Japan, Mexico, Bolivia, Australia, Spain, India, UK, Poland etc. [15]. Earthships are low-budget buildings, that can function in any climate. They are energy efficient, very well insulated from the environment and varied in shapes. These buildings can be built both on the ground and beneath it, where the insulation from the environmental conditions is bigger. The philosophy of building this type of building is based primarily on self-sufficiency, which means not only the reduction of utility bills, but also the on-the-spot production of food, and the use of water in continuous circulation. The height and width of the building depends only on the creativity and imagination of the designer and contractor and on construction possibilities. These houses do not affect the quality of the landscape in a negative way, and with a proper design they can also enrich it.

Underground houses are also a good investment of capital, because they will certainly not lose value. By observing the real estate market, there are more and more luxurious residences, which, apart from the living space above the ground level, have - often a multi-storey extended underground part of the building. London can serve as an example of a city in which we find many such offers of this kind. Furthermore, it can be predicted, that in several decades building buildings underground cities may become a part of every-day reality.

In 1996, ACUUS (Associated Research Centers for the Urban Underground Space) was established, whose aim was to focus on raising awareness and promoting use of underground space of our cities and changing the paradigm of the sustainable development of urban tissue. 
[16]. The organization conducts open discussion in a variety of environments - both at the university level, at the art and decision level, on urban and suburban urban space integration. Perhaps by promoting a new way of thinking about urban development, it is possible to achieve the state of sustainable development in urban space?

\section{Advantages and disadvantages of underground houses and cities}

Houses, built underground, in spite of their great advantages, have disadvantages and often generate a lot of controversy and emotion. It has been argued that underground housing is associated with humidity, darkness, insects, rodents, etc. It is often a taboos subject. Moreover, the psychological aspect plays a very important role, where the feeling of security, control or ordinary claustrophobia can determine our emotions, related with this type of houses. Also, the materials, from which we make houses, are not indifferent to people. For example, underground houses cannot be made of wood but wood can be put on the walls. When deciding, whether to build a house completely or partially underground, all the pros and cons of such investment should be taken into account. Also a cost account should be done. Advantages and disadvantages of constructing underground houses have been presented in the table 1.

Table 1. Advantages and disadvantages of the houses underground construction.

\begin{tabular}{|c|c|}
\hline Advantages & Disadvantages \\
\hline $\begin{array}{l}\text { - } \quad \text { lower construction costs compared to } \\
\text { conventional one, } \\
\text { - } \quad \text { lower home maintenance costs, } \\
\text { checked for a multi-years housing } \\
\text { - } \quad \text { system, } \\
\text { - } \quad \text { resistance to earthquakes and tornadoes, } \\
\text { - } \quad \text { safe live environment in extreme weather } \\
\text { condiotions } \\
\text { - } \quad \text { fire resistance, } \\
\text { - } \quad \text { energh saving, } \\
\text { - large acoustic insulation, } \\
\text { - } \quad \text { use of less materials than in conventional } \\
\text { houses, and in case of Eartship homes use } \\
\text { of recycled materials } \\
\text { leaving the area for plants and animals - } \\
\text { supporting natural ecological processes } \\
\text { and maintaining high quality habitats } \\
\text { Significant impact on the CO } \mathrm{CO}_{2} \text { reduction in } \\
\text { the atmosphere by reducing the energy } \\
\text { demand and leaving on the earth surface } \\
\text { vegetated areas, biotopes support and } \\
\text { biological diversity, } \\
\text { minimal impact on the landscape. }\end{array}$ & 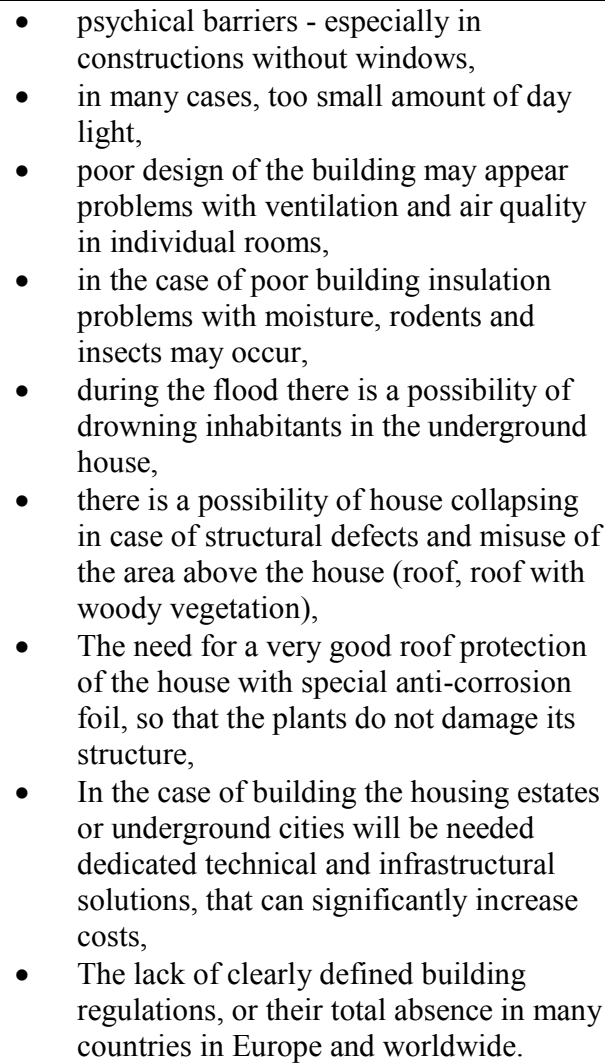 \\
\hline
\end{tabular}


The construction of underground cities nowadays is an enormous challenge in terms of technic, infrastructure and logistics. The relocation of cities, roads, factories underground will cause many problems, including water supply, sewage, waste disposal, ventilation, lightening or psychosomatic barriers [17]. Part of the technical solutions we already have, because on the one hand there are experiences of our ancestors living in the underground cities or the experiences of Coober Pedy residents in Australia. We also have well-developed subway lines in which people live every day, or shopping malls, where there are parts at levels of at least minus 1. People's psychological barrier to use the underground is slowly breaking. People often do not even realize how much time they really spend underground. On the other hand, these cities may be more exposed to terrorist attacks because of their location.

\section{Conclusion}

Urban fabric in every corner of the world annually grows at a rapid pace. In the world one can observe two dominant phenomena. The first is related to the movement of people from villages to urban areas, so that the living space in the city starts to shrink. The second, called urban sprawl, means quite an uncontrolled spillover of urban structure, due to the increasing number of population in the city. In spots of green squares there are buildings, greenery is transferred to roofs and vertical gardens are created. But it's still not enough. We eliminate nature from our cities and destroy the natural environment. It is predicted that in the year 2050 the human population may reach over 9 trillion people, and at least $2 / 3$ of them will live in cities [16]. In the emerging megacities and metropolis, space became a scarce commodity. We are already seeing a rise in flats and house prices in big metropolises, such as in Tokyo, Mexico City, London, Paris, New York, etc. There are increasing problems with road infrastructure and communication. This problem will grow year by year due to the systematic increase in the number of cars - in some cities their numbers increase faster than the population [16]. This situation is reflected in the deteriorating air quality, and the construction of high and near situated skyscrapers only aggravates it, rising the problem of urban ventilation system. Modern, bustling day and night cities and towns are extremely energy-consuming, contributing indirectly to the increase of $\mathrm{CO}_{2}$ in the atmosphere. Landscape values are often severely disturbed, which indirectly influences the comfort of the people. Due to urban overcrowding and environmental problems, it would be better to consider the possibility of a gradual relocation of all or part of the land-based investment, including the entire road infrastructure and housing. Of course, this process will be progressing gradually and for many years, but thanks to its initiation and further realization we will gain not only new surfaces for the lives of people on our planet but will also have a positive impact on the world of plants and animals. Leaving on the surface of green gardens or natural forests and habitats will have a huge impact on the quality of the natural environment in every dimension, including landscape one. So we are left with a change of the cities design paradigm of and meeting the nature.

\section{References}

1. K. Ronka, J. Ritola, K. Rauhala, Tunnel. and Underground. Space Technology 13, 1, 39-49 (1998)

2. A. J. Anselm, Energ. and Build. 40, 1214-1219 (2008)

3. S.A. Alkaff, S.C. Sim, M.N.E. Efzan, Renew. and Sustain. Energ. Review 60, 692-713 (2016) 
4. A.A. Al-Mumin, Energ. and Build. 33, 103-111(2001)

5. A.A. Al-Tameemi, D.J. Harris, Energ. and Build. 36, 251-260 (2004)

6. M. Khodabakhshian, Proced. Engineering 165, 649-657 (2016)

7. L. Kralovičová, I. Šimková, J. Vlčko, T. Durmeková, M. Brček, V. Boháč, Acta Geol. Slov. 6, 1, 41-50 (2014)

8. UNESCO: http://whc.unesco.org/en/tentativelists/5234/ on line 17.03.2017

9. A. Erdem, Y. Erdem, Underground space use. Analysis of the Past and Lessons for the Future, 35-39 (2005)

10. K. Labs, Underground Space 1, 135-156 (1976)

11. H. Altan, M. Hajibandeh, K. Anissa, T. Aoul, A. Deep, Passive Design, ZEMCH: Toward the Delivery of Zero Energy Mass Custom Homes, 209-236 (2016)

12. A. Benardos, I. Athanasiadis, N. Katsoulakos, Tunnel. and Underground. Tech. 41, 46-52 (2014)

13. A. De Munari, D.P.S Capão, S.S. Richards, A.I. Schäfer, Desalination 248, 72-82 (2009)

14. M. Reynolds, Eartship: How to build your own, 1 (1990)

15. K. Ip, A. Miller, Renew. Energ. 34, 2037-2043 (2009)

16. D. Kaliampakos, Proced. Engineer. 165, 205-213 (2016)

17. D. Kaliampakos, A. Benardos, WIT Transactions on the Built Environment 102, 1743-3509 (2017) 